\title{
Meningkatkan Hasil Belajar IPA Materi Ekosistem Dengan Permainan Kartu Bioma Pada Siswa Kelas V SDN Murbaya Tahun Pelajaran 2019 /2020
}

\author{
Suhirman \\ Guru Kelas SDN Murbaya Kec. Pringgarata Kab. Lombok Tengah
}

\begin{abstract}
Abstrak. Jenis penelitian ini adalah Penelitian Tindakan Kelas dengan subjek penelitian siswa kelas V SDN Murbaya yang berjumlah 18 orang Penelitian ini berlangsung dalam dua siklus. Instrumen yang digunakan adalah lembar tes. Data dianalisis secara deskriptif kualitatif dan kuantitatif. Indikator keberhasilan penelitian ini adalah jika minimal $\geq 80 \%$ siswa telah mencapai KKM yaitu 70 dan nilai rata-rata kelas mengalami peningkatan tiap siklusnya. Berdasarkan kedua data tersebut diatas maka terlihat peningkatan hasil belajar yang signifikan pada siklus dengan menggunakan permainan kartu bioma diperoleh nilai rata - rata sebesar 67 kemudian pada siklus II memperoleh nilai rata - rata sebesar 83 terjadi peningkatan sebesar 16 poin, kemudian jumlah siswa yang tuntas belajar pada siklus I sebanyak 10 siswa dengan persentase sebesar $55 \%$ kemudian pada siklus II jumlah siswa yang tuntas sebanyak 16 siswa dengan persentase ketuntasan sebesar $88 \%$ terjadi peningkatan sebesar 33 poin, dengan demikian semua indikator keberhasilan yang dipatok telah berhasil dicapai, maka penelitian ini dihentikan sampai pada siklus II. Dengan demikian dapat ditarik kesimpulan bahwa dengan menggunakan permainan kartu bioma d apat meningkatkan hasil belajar IPA materi ekosistem pada siswa kelas V SDN Murbaya tahun pelajaran 2019 / 2020
\end{abstract}

Kata kunci: Hasil Belajar IPA dan permainan kartu bioma.

\section{PENDAHULUAN}

Tempat tinggal alami bagi tumbuhan atau hewan disebut habitat. Setiap habitat dihuni oleh komunitas ( Kelompok ) mahluk hidup yang berbeda. Suatu ekosistem tersusun atas habitat dan komunitas. Mahluk hidup yang berbeda dalam ekosistem saling berinteraksi. Mahluk hidup tersebut juga berinteraksi dengan benda mati yang ada dilingkungannya ( disekitarnya) seperti air atau udara.Ekosistem Bumi Kita merupakan ekosistem yang besar menurut ilmu ekologi.

Upaya meningkatkan hasil belajar siswa merupakan tantangan yang selalu dihadapi oleh setiap orang yang berkecimpung dalam dunia pendidikan. Banyak upaya yang telah dilakukan dan banyak pula keberhasilan yang telah dicapai, meskipun keberhasilan itu belum sepenuhnya memberikan kepuasan bagi masyarakat dan para guru, sehingga sangat menuntut renungan, pemikiran dan kerja keras orangorang yang berkecimpung di dunia pendidikan untuk memecahkan masalah yang dihadapi. "Guru dikatakan berhasil apabila pembelajaran yang diberikan mampu mengubah perilaku sebagian besar peserta didik kearah penguasaan kompetensi dasar yang lebih baik( Kaswara;2008;3).

Kemampuan guru dalam menggunakan metode yang sesuai dengan tujuan dan materi pelajaran merupakan kunci keberhasilan dalam pencapaian prestasi belajar siswa. Tuntutan tersebut mutlak dilakukan oleh seorang guru dalam proses pembelajaran khususnya dalam belajar IPA. Hal tersebut juga sejalan dengan tuntutan kurikulum saat ini yang sangat memperhatikan kepentingan metode-metode pembelajaran yang digunakan. Guru dituntut untuk pandai-pandai dalam memilih metode atau model pembelajaran yang tepat, karena "ciri-ciri guru yang baik adalah guru yang bisa menyesuaikan metode mengajar dengan bahan pembelajaran.(Muhibbin 2010;1)

Berdasarkan hasil ulangan harian yang dilaksanakan di SDN Murbaya pada mata pelajaran IPA materi Ekosistem dari 18 siswa yang tuntas belajar hanya 5 siswa dengan persentase sebesar $28 \%$ dan siswa yang belum tuntas sebanyak 13 siswa dengan persentase sebesar $72 \%$, sedangkan KKM yang ditetapkan di SDN Murbaya untuk 
Mata Pelajaran IPA pada tahun pelajaran 2019 / 2020 adalah 70 dengan ketuntasan klasikal sebesar $\geq 80 \%$.

Ternyata rendahnya hasil belajar siswa dikarenakan tidak menggunakan media pembelajaran sehingga siswa menjadi bosan karena tidak ada yang menjadi jembatan penghubung antara guru dan siswa sehingga tujuan pembelajaran dapat tercapai , dalam Pembelajaran IPA harus melibatkan keaktifan peserta didik secara penuh (Active Learning) dengan merealisasikan pembelajaran yang mampu memberikan kesempatan pada peserta didik untuk melakukan keterampilannya sendiri. Adapun keterampilan tersebut meliputi: kemampuan mencari, menemukan, menyimpulkan, mengkomunikasikan sendiri berbagai pengetahuan, nilai-nilai dan pengalaman yang dibutuhkan. Pembelajaran IPA yang baik harus mengaitkannya dengan kehidupan sehari-hari siswa. Pembelajaran IPA pada tingkat sekolah dasar sebisa mungkin didasarkan pada pendekatan empirik dengan asumsi bahwa alam raya ini dapat dipelajari, dipahami dan dijelaskan,

Kenyataan yang telah dipaparkan di atas merupakan alasan yang membuat peneliti tertarik untuk meneliti dan mencoba menerapkan penggunaan media pembelajaran yang baru berupa permainan Kartu Bioma dimana siswa dapat mencoba secara langsung apa yang ingin dicari secara langsung sebagai media transformasi konsep yang disampaikan dalam pembelajaran sehingga memilih judul " Meningkatkan Hasil Belajar IPA Materi Ekosistem dengan permainan kartu bioma pada Siswa Kelas V SDN Murbaya Tahun Pelajaran 2019 /2020."

\section{Rumusan Masalah}

Dari latar belakang diatas maka masalah yang dikaji dalam penelitian ini dapat dirumuskan sebagai berikut Bagaimanakah Meningkatkan Hasil Belajar IPA Materi Ekosistem dengan permainan kartu bioma pada Siswa Kelas V SDN Murbaya Tahun Pelajaran 2019 /2020."

\section{Tujuan Penelitian}

Berdasarkan rumusan masalah di atas, maka tujuan penelitian ini adalah Untuk Meningkatkan Hasil Belajar IPA
Materi Ekosistem dengan permainan kartu bioma pada Siswa Kelas V SDN Murbaya Tahun Pelajaran 2019 /2020."

\section{Manfaat Penelitian}

Penelitian ini diharapkan dapat memberikan manfaat secara teoritis maupun praktis: Secara teoritis penelitian ini memperkaya khasanah ilmu pendidikan yang berhubungan dengan penerapan metode pembelajaran yang tepat bagi peserta didik. Meningkatkan kreatifitas seorang pendidik dalam memberikan metode pembelajaran bagi peserta didiknya sehingga peserta didik dengan mudah menerima penjelasan dan pengetahuan yang diberikan oleh pendidik (guru). Secara praktis penelitian ini, dapat dijadikan referensi dan tambahan pengetahuan tentang pendekatan dan media pembelajaran yang baik seuai dengan materi yang akan di ajarkan

\section{LANDASAN TEORI DAN KAJIAN PUSTAKA}

Pengertian Ilmu Pengetahuan Alam (IPA)

Ilmu Pengetahuan Alam (IPA) berhubungan dengan cara mencari tahu tentang alam secara sistematis, sehingga IPA bukan hanya penguasaan kumpulan pengetahuan yang berupa fakta-fakta, konsepkonsep, atau prinsip-prinsip saja tetapi juga merupakan suatu proses penemuan. Kata IPA merupakan terjemahan dari bahasa inggris yaitu "Natural Science" secara singkat sering disebut "science. "Sains (Science) diambil dari bahasa latin yang arti harfiahnya adalah pengetahuan. Adapun pengetahuan itu sendiri artinya segala sesuatu yang diketahui oleh manusia. Jadi secara singkat IPA adalah pengetahuan rasional dan objektif tentang alam semesta dengan segala isinya. Jadi ilmu pengetahuan alam merupakan ilmu yang pokok bahasannya adalah alam dan segala isinya"( Triyanti; 2010; 100)

Adapun Wahyana dalam Triyanto mengatakan bahwa IPA adalah suatu kumpulan pengetahuan tersusun secara sistematik dan dalam penggunaannya secara umum terbatas pada gejala-gejala alam".(Triyanto; 2010; 136) Sedangkan "Menurut H.W Fowler dalam Triyanto IPA adalah pengetahuan yang sistematis, dirumuskan dan berhubungan dengan gejala- 
gejala kebendaan dan didasarkan atas pengamatan dan dedikasi"( Triyanto; 2010; 136) Dari paparan di atas dapat disimpulkan bahwa IPA adalah suatu kumpulan teori yang sistematis yang pokok bahasannya adalah gejala-gejala alam dan segala isinya.

\section{Hakikat dan Karakteristik IPA di SD}

Hakikat IPA memiliki empat unsur yang utama yaitu pertama, sikap ingin tahu tentang benda, fenomena alam, mahluk hidup serta hubungan sebab akibat yang menimbulkan masalah baru yang dapat dipecahkan melalui prosedur yang benar. Kedua, proses prosedur pemecahan masalah: Metode ilmiah meliputi penyusunan hipotesis, perencanaan, eksperimen, evaluasi, pengukuran dan penarikan kesimpulan. Ketiga, Produk: berupa fakta, prinsip, teori dan hukum. Keempat, Aplikasi: penerapan metode dan konsep IPA dalam kehidupan sehari-hari. Keempat unsur tersebut merupakan ciri IPA yang utuh serta tidak dapat dipisahkan satu sama lain" ( Triyanti; 2010; 100)

\section{Fungsi dan Manfaat Media Pembelajaran}

Menurut Badru Zaman dalam buku manajemen sarana dan prasarana sekolah media pembelajaran pada dasarnya sebagai: "Wahana dari pesan yang oleh sumber pesan (guru) ingin diteruskan kepada penerima pesan (anak). Pesan yang disampaikan adalah isi pembelajaran dalam bentuk tema/ topic pembelajaran dengan tujuan agar terjadi proses belajar pada diri anak" ( Badru Zaman ;3 ).

$$
\text { Empat fungsi media }
$$

pembelajaran, khususnya media visual menurut Azhar Arsyad, yaitu:

- Pertama, fungsi atensi sering media visual merupakan inti, yaitu menarik dan mengarahkan perhatian siswa untuk berkonsentrasi kepada isi pelajaran berkaitan dengan makna visual yang ditampilkan atau menyertai teks materi pelajaran.Sering kali pada awal pembelajaran siswa tidak tertarik dengan materi pembelajaran atau mata pelajaran itu merupakan salah satu pelajaran yang tidak disenangi oleh mereka sehingga mereka tidak memperhati- kannya. Media gambar yang diproyeksikan dapat menenangkan dan mengarahkan perhatian mereka kepada pelajaran yang akan diterima. Sehingga untuk memperoleh dan mengingat isi pelajaran semakin besar.

- Kedua, fungsi afektif media visual dapat terlihat dari tingkat kenikmatan siswa saat ketika belajar atau membaca teks yang bergambar.

- Ketiga fungsi kognitif media visual akan memperlancar pencapaian tujuan untuk memahami dan mengingat informasi atau pesan yang terkandung dalam gambar.

- Keempat fungsi kompensatoris media visual memberikan pemahaman bagi siswa yang lemah dan lambat menerima dan memahami isi pelajaran yang disajikan ( Azhar Arsyad ; 21).

Fungsi media pembelajaran adalah untuk membantu guru dan mempermudah anak dalam proses belajar mengajar. Sedangkan Arif berpendapat Media pembelajaran berfungsi sebagai berikut: a) Membantu memudahkan belajar bagi anak dan juga memudahkan proses pembelajaran bagi guru, b) Memberikan pengalaman lebih nyata (abstrak menjadi konkrit), c) Menarik perhatian anak lebih besar (jalannya pelajaran tidak membosankan), d) Semua indera anak dapat diaktifkan, e) Dapat membangkitkan dunia teori dengan realitanya Ariep dkk,2006; $6)$.

Dengan menggunakan media pembelajaran anak akan lebih mudah memahami dan menyerap pembelajaran. dan fungsi media bagi guru akan mempermudah guru dalam menyampaikan dan menyalurkan pesan-pesan yang akan disalurkan.

Menurut Badru Zaman, banyak manfaat yang dapat diperoleh dengan memanfaatkan media dalam pembelajaran yaitu:

1. Pesan/informasi pembelajaran dapat disampaikan dengan lebih jelas, menarik, kongkrit dan tidak hanya dalam bentuk kata-kata tertulis atau lisan belaka (verbalistis). 
2. Mengatasi keterbatasan ruang, waktu, dan daya indera. Misalnya objek yang terlalu besar dapat digantikan dengan realita, gambar, film bingkai, film atau model.kejadian atau peristiwa yang terjadi di masa lalu dapat ditampilkan lagi lewat rekaman film, video, dan lain-lain. Objek yang terlalu kompleks dapat disajikan dengan model, diagram dan lain-lain.

3. Meningkatkan sikap aktif siswa dalam belajar.

4. Menimbulkan kegairahan dan motivasi dalam belajar.

5. Memungkinkan interaksi yang lebih langsung antara siswa dengan lingkungan dan kenyataan.

6. Memungkinkan siswa belajar sendirisendiri menurut kemampuan dan minatnya.

7. Memberikan perangsang, pengalaman dan persepsi yang sama bagi siswa Badru ( Badru Zaman; 4).

Seorang guru SD selalu menginginkan agar pesan yang disampaikannya dapat diterima anak dengan afektif dan efisien. Untuk itu diperlukan media pembelajaran. Media yang dikembangkan dengan baik diharapkan dapat membantu anak memahami pesan yang disampaikan kepada anak.

Dari uraian diatas dapat disimpulkan beberapa manfaat praktis dari penggunaan media pembelajaran di dalam proses belajar yaitu media dapat memperjelas penyajian pesan dan informasi, media dapat meningkatkan dan mengarahkan perhatian anak sehingga dapat menimbulkan motivasi belajar, media pembelajaran dapat mengatasi keterbatasan indera, ruang dan waktu dan media pembelajaran dapat memberikan kesamaan pengalaman kepada anak tentang peristiwa-peristiwa di lingkungan mereka.

\section{Media Pembelajaran}

Bila dikaitkan dengan pembelajaran anak SD maka media dimaksudkan sebagian alat yang menjadi perantara dalam menyampaikan pembelajaran pada anak usia dini. Dalam konteks ini, terdapat banyak media yang bisa digunakan untuk pembelajaran anak usia dini. Prinsipnya, media yang akan digunakan tersebut dapat memberikan rangsangan semangat atau motivasi anak usia dini untuk dapat belajar dengan mudah dan menyenangkan sehingga mereka tidak merasa jenuh atau bosan dalam mengikuti prosesbelajar.

Media pembelajaran dapat dikelompokkan menjadi tiga bagian yaitu media visual, audio, dan audiovisual. Media pembelajaran ini adalah salah satu komponen yang sangat penting dalam proses pembelajaran. Media pembelajaran dapat meningkatkan kualitas hasil belajar.

\section{Permainan Kartu Bioma}

Bumi tersusun dari ekosistem ekosistem yang besar yang disebut bioma. Bioma diberi nama berdasarkan jenis vegetasi (tumbuhan ) yang paling banyak tumbuh ditempat tersebut.Bioma terbentuk karena dipengaruhi oleh iklim, apakah ada di daerah kering, dingin, basah, atau panas. Hutan topis mendapat banyak sinar matahari , gurun beriklim panas dan kering ,wilayah tundra dingin membeku, setiap tempat memiliki jaring - jaring makanan tersendiri, tersusun dari mahluk hidup yang telah beradaptasi dengan iklim setempat.

\section{Langkah - langkah dalam membuat kartu bioma antara lain :}

1. Permainan kartu bioma untuk memainkan permainan ini, kamu memerlukan kartu tebal, gunting dan pensil warna. Setiap set kartu menunjukkan rantai makanan pada bioma yang berbeda

2. Buatlah 30 potong kartu tirulah gambar apa yang ingin ditulis sehingga kita membuat dua set gambar untuk setiap rantai makanan dan enam kartu matahari, kemudian beri nomor pada setiap kartu.

3. Permainan ini dapat dimainkan oleh dua orang atau lebih . tujuannya untuk mengumpulkan empat kartu yang dengan empat kartu berada dalam set kartu tyang tepat, semua set kartu harus memiliki matahari, setiap pemain mulai , kemudian secara bergiliran mengambil satu kartu dari tumpukan kartu yang tersisa. Simpan kartu yang diambil atau kembalikan kartu rtersebut ditumpukan paling bawah.Orang yang pertama 
mengumpulkan rantai makanan paling lengkap dialah pemenangnya.

\section{METODE PENELITIAN}

\section{Setting Penelitian}

Jenis penelitian yang dilakukan oleh peneliti adalah penelitian tindakan kelas (Classroom Action Research). "Penelitian Tindakan Kelas (PTK) adalah suatu pencermatan terhadap kegiatan belajar berupa sebuah tindakan yang sengaja dimunculkan dan terjadi dalam sebuah kelas secara bersama".(Arikunti;2009; 3) Adapun langkah-langkah dalam setiap siklus adalah sebagai berikut: Perencanaan tindakan pelaksanaan tindakan, mengobservasi, mengevaluasi dan refleksi.

\section{Tempat dan waktu penelitian}

Penelitian ini akan dilakasanakan di SDN Murbaya yang beralamat di Desa Murbaya Kecamatan Pringgarata Kabupaten Lombok tengah, pada semester I Tahun Pelajaran 2019 /2020, Mulai dari bulan Oktober sampai dengan bulan Desember 2019 Tahun pelajaran 2019 / 2020.

\section{Subyek Penelitian}

Subyek penelitian ini adalah siswa kelas $\mathrm{V}$ yang berjumlah 18 orang terdiri dari 6 siswa laki - laki dan 9 siswa perempuan ,mereka berasal dari sekitar lingkungan sekolah, dengan kemampuan yang beragam ada yang sangat pandai, ada yang sedang dan ada yang kurang pandai.

\section{Rencana Tindakan}

Penelitian ini direncanakan dalam dua siklus.. Masing-masing siklus terdiri dari empat tahapan kegiatan yaitu perencanaan tindakan, pelaksanaan tindakan, observasi dan evaluasi, serta refleksi.( arikunto ;2013; 137) Adapun model dan penjelasan untuk masingmasing tahap adalah sebagai berikut.

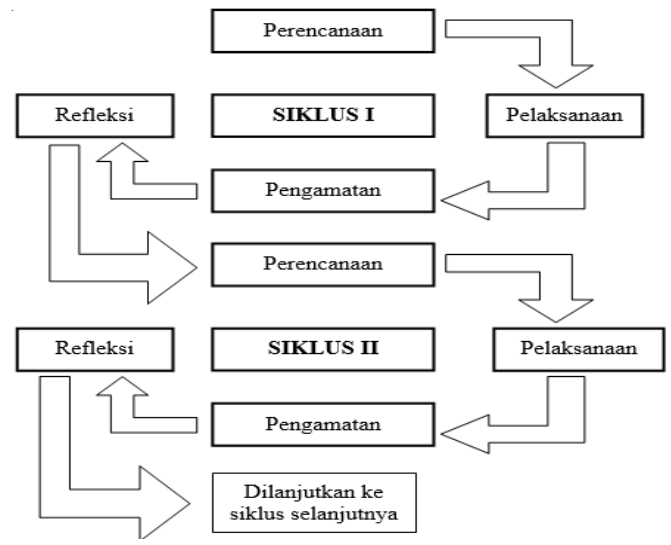

Gambar 1.2 : Siklus Penelitian Tidaka

Jenis Instrument dan Cara
Penggunaannya

Jenis instrument yang digunakan untuk mengumpulkan data dalam penelitian ini adalah: Tes Tulis/ Tes Isian (Completion test). Completion test biasanya kita sebut dengan istilah tes isian, tes menyempurnakan atau tes isian Completion test terdiri atas kalimat-kalimat yang ada bagian-bagiannya yang dihilangkan.( Arikunto; 2009; 175) Bagian yang dihilangkan atau yang harus diisi oleh siswa merupakan pengertian yang kita minta dari murid. Adapun tes isian yang diberikan pada setiap siklus berjumlah 10 soal dengan nilai skor 10 pada masing-masing soal.

Analisis data adalah suatu cara yang digunakan dalam pengolahan data yang telah terhimpun dari hasi belajar siswa, sehingga diperoleh informasi-informasi yang guna, dan kemudian dianalisis.

Setelah memperoleh data tes hasil belajar, maka data tersebut dianalisis dengan mencari ketuntasan belajar dan daya serap, kemudian dianalisis secara kuantitatif.

1) Ketuntasan Individu

$\mathrm{P}=\frac{X}{S M I} \times 100$

Keterangan:

$\mathrm{P}=$ Persentil

$\mathrm{X}=$ Skor yang dicapai

SMI = Skor Maksimal Ideal( Wayan Nurkencana;99)

2) Ketuntasan Klasikal

$\mathrm{KK}=\frac{\mathrm{x}}{\mathrm{z}} \mathrm{x} 100 \%$

Keterangan :

KK : Ketuntasan Klasikal

$\mathrm{X} \quad$ : Jumlah siswa yang mencapai nilai $\geq$ 75

$\mathrm{Z}$ : Jumlah siswa keseluruhan( Wayan Nurkencana;99)

\section{HASIL PENELITIAN DAN \\ PEMBAHASAN \\ Hasil Penelitian}

Penelitian ini dilaksanakan di Kelas V SDN Murbaya yang beralamat di Desa Murbaya Kecamatan Pringgarata yang dimulai pada tanggal 24 Oktober 2019 
sampai dengan Desember 2019, sesuai dengan surat keterangan telah melaksanakan penelitian yang dikeluarkan oleh SDN Murbaya Kecamatan Pringgarata.

\section{Siklus I}

Pelaksanaan pembelajaran pada siklus ini dilaksanakan pada tanggal 24 September 2019 yang, dimana peneliti bertindak sebagai pengajar Proses pelaksanaan dilalukan sesuai dengan skenario pembelajaran yang telah disiapkan. Adapun hasil belajar pada siklus I adalah nilai rata rata yang di peroleh siswa sebesar 67 jumlah siswa yang tuntas belajar sebanyak 10 siswa dengan persentase ketuntasan sebesar $55 \%$ dan siswa yang belum tuntas belajar sebanyak 8 siswa dengan persentase $44 \%$ dan ketuntasan klasikal yang dipersyaratkan sebesar $\geq 80 \%$ belum tercapai baru mencapai $55 \%$, ini dikarenakan siswa masih belum paham dengan petunjuk yang di tuliskan pada LKS dan guru kurang kontrol dalam pengelolaan kelas, maka dengan demikian penelitian dilanjutkan ke siklus berikutnya.

\section{Tahap Pengamatan/Observasi}

Observasi yaitu kegiatan pengamatan yang dilakukan oleh pengamat. Tujuan dilakukannya pengamatan atau observasi adalah untuk mengumpulkan bukti hasil tindakan agar dapat dievaluasi dan dijadikan landasan dalam melakukan refleksi.

\section{Tahap Refleksi}

Refleksi dilakukan pada akhir siklus, hasil refleksi ini digunakan sebagai dasar untuk memperbaiki serta menyempurnakan perencanaan dan pelaksanaan tindakan pada siklus selanjutnya.

\section{Siklus II}

Kegiatan penelitian dilanjutkan ke siklus II yang diprogramkan pada tanggal 20 Oktober 2019 dengan alokasi waktu $3 \mathrm{x}$ 35 menit, adapun hal-hal yang dilakukan pada siklus II tidak jauh berbeda dengan yang dilakukan pada siklus sebelummya. langkah - langkah pembelajaran yang dilakukan pada siklus II sesuai dengan agenda yang sudah tertuang dalam RPP dan pada kegiatan akhir diadakan evaluasi dan , hasil belajar siswa pada siklus Dari tabel hasil belajar siswa diatas dengan permainan menggunakan kartu bioma diperoleh data nilai rata - rata yang diperoleh sebesar 83 jumlah siswa yang tuntas belajar sebanyak 16 siswa dengan persentase ketuntasan sebesar $88 \%$ dan siswa yang belum tuntas sebanyak 2 siswa dengan persentase $12 \%$ begitu juga dengan ketuntasan klasikal sudah lebih besar dari target yaitu sebesar $\geq 80 \%$, ini dikarenakan guru mampu mengatasi kendala yang terjadi pada siklus I siswa sudah merasa senang dengan permainan kartu bioma yang disajikan, sehingga hasil belajar siswa mencapai apa yang ditargetkan, maka dengan demikian penelitian dihentikan sampai siklus II.

\section{Tahap Pengamatan/Observasi}

Observasi yaitu kegiatan pengamatan yang dilakukan oleh pengamat. Tujuan dilakukannya pengamatan atau observasi adalah untuk mengumpulkan bukti hasil tindakan agar dapat dievaluasi dan dijadikan landasan dalam melakukan refleksi.

\section{Tahap Refleksi}

Refleksi dilakukan pada akhir siklus, hasil refleksi ini digunakan sebagai dasar untuk memperbaiki serta menyempurnakan perencanaan dan pelaksanaan tindakan pada siklus selanjutnya.

\section{Pembahasan}

Penelitian ini dilaksanakan sesuai dengan prosedur penelitian tindakan kelas yang telah ditetapkan yaitu diawali dengan perencanaan, pelaksanaan tindakan, observasi dan refleksi seperti yang telah dijelaskan pada penelitian di atas. Penelitian ini dilaksanakan mulai dari bulan Oktober sampai dengan Desember 2019 di kelas V SDN Murbaya tahun pelajaran 2019 / 2020. Terjadi peningkatan hasil belajar mulai dari siklus I sampai siklus II terjadi peningkatan yang signifikan brdasarkan data yang diperoleh.

Hasil belajar siswa siklus I dengan menggunakan permainan kartu bioma diperoleh nilai rata - rata yang sebesar 67 jumlah siswa yang tuntas belajar sebanyak 10 siswa dengan persentase ketuntasan sebesar $55 \%$ dan siswa yang belum tuntas belajar sebanyak 8 siswa dengan persentase $44 \%$ dan ketuntasan klasikal yang dipersyaratkan sebesar $\geq 80 \%$ belum tercapai baru mencapai $55 \%$, ini dikarenakan siswa masih 
belum paham dengan petunjuk yang di tuliskan pada LKS dan guru kurang kontrol dalam pengelolaan kelas, maka dengan demikian penelitian dilanjutkan ke siklus berikutnya.

Dari tabel hasil belajar siswa diatas dengan permainan menggunakan kartu bioma diperoleh data nilai rata - rata yang diperoleh sebesar 83 jumlah siswa yang tuntas belajar sebanyak 16 siswa dengan persentase ketuntasan sebesar $88 \%$ dan siswa yang belum tuntas sebanyak 2 siswa dengan persentase $12 \%$ begitu juga dengan ketuntasan klasikal sudah lebih besar dari target yaitu sebesar $\geq 80 \%$, ini dikarenakan guru mampu mengatasi kendala yang terjadi pada siklus I siswa sudah merasa senang dengan permainan kartu bioma yang disajikan, sehingga hasil belajar siswa mencapai apa yang ditargetkan, maka dengan demikian penelitian dihentikan sampai siklus II.

Berdasarkan kedua data tersebut diatas maka terlihat peningkatan hasil belajar yang signifikan pada siklus dengan menggunakan permainan kartu bioma diperoleh nilai rata - rata sebesar 67 kemudian pada siklus II memperoleh nilai rata - rata sebesar 83 terjadi peningkatan sebesar 16 poin, kemudian jumlah siswa yang tuntas belajar pada siklus I sebanyak 10 siswa dengan persentase sebesar $55 \%$ kemudian pada siklus II jumlah siswa yang tuntas sebanyak 16 siswa dengan persentase ketuntasan sebesar $88 \%$ terjadi peningkatan sebesar 33 poin, dengan demikian semua indikator keberhasilan yang dipatok telah berhasil dicapai, maka penelitian ini dihentikan sampai pada siklus II.

Dengan demikian dapat ditarik kesimpulan bahwa dengan menggunkan permainan kartu bioma d apat meningkatkan hasil belajar IPA materi ekosistem pada siswa kelas V SDN Murbaya tahun pelajaran 2019 / 2020

PENUTUP

Simpulan

Penelitian ini dilaksanakan di SDN Murbaya dengan jumlah subyek penelitian sebanak 18 siswa pada mata pelajaran IPA semester I dari bulan September sampai dengan bulan Desember 2019 tahun pelajaran 2019 / 2020, kemudian penelitian ini dilaksanakan sesuai dengan prosedur penelitian tindakan kelas yang telah ditetapkan yaitu diawali dengan perencanaan, pelaksanaan tindakan, observasi dan refleksi seperti yang telah dijelaskan pada penelitian di atas.

Berdasarkan kedua data tersebut diatas maka terlihat peningkatan hasil belajar yang signifikan pada siklus dengan menggunakan permainan kartu bioma diperoleh nilai rata - rata sebesar 67 kemudian pada siklus II memperoleh nilai rata - rata sebesar 83 terjadi peningkatan sebesar 16 poin, kemudian jumlah siswa yang tuntas belajar pada siklus I sebanyak 10 siswa dengan persentase sebesar $55 \%$ kemudian pada siklus II jumlah siswa yang tuntas sebanyak 16 siswa dengan persentase ketuntasan sebesar $88 \%$ terjadi peningkatan sebesar 33 poin, dengan demikian semua indikator keberhasilan yang dipatok telah berhasil dicapai, maka penelitian ini dihentikan sampai pada siklus II.

Dengan demikian dapat ditarik kesimpulan bahwa dengan menggunkan permainan kartu bioma dapat meningkatkan hasil belajar IPA materi ekosistem pada siswa kelas V SDN Murbaya tahun pelajaran 2019 / 2020

\section{DAFTAR PUSTAKA}

Arikunto, Suharsimi, Dasar-dasar Evaluasi Pendidikan. Jakarta: Bumi Aksara, 2009.

Arikunto, Suharsimi, dkk. Penelitian Tindakan kelas. Jakarta: Bumi Aksara, 2009

Arikunto, Suharsimi, Dkk. Prosedur Penelitian Suatu Pendekatan Praktik. Jakarta: Rineka Cipta, 2013.

Djamarah, Syaiful Bahri. Dkk. Strategi Belajar Mengajar. Jakarta: Rineka Cipta, 2013.

http://duniabaca.com/Pengertian belajar dan hasil belajar.html/

Kaswara, Deni. Bagaimana Menjadi Guru Kreatif. Bandung: Bumi Aksara, 2008.

Muhibbin Syah. Psikologi Belajar. Jakarta: Rajawali Pers, 2010. 
Mulyati, Arifin. Dkk. Ilmu Pengetahuan Alam dan Lingkungan Untuk KELAS VI SD/MI. Jakarta: PT Setia Purna Invest, 2008.

Nasution. Berbagai Pendekatan Dalam Proses Belajar dan Mengajar. Jakarta: PT Bumi Aksara, 2009.

Purwanto, Evaluasi Hasil Belajar, Yogykarta:Pustaka Pelajar. 2010.

Purwanto, Ngalim. Evaluasi Hasil Belajar. Yogyakarta: Pustaka Pelajar, 2010 .

Sagala, Syaiful. Makna dan Konsep Pembelajaran. Bandung: Alfabeta, 2006.

Slameto. Belajar dan Faktor-faktor yang Mempengaruhinya. Jakarta: Rineka Cipta, 2010.

Sudjana, Nana. Dasar-dasar Proses Belajar Mengajar. Bandung: Sinar Baru Aglensindo. 2011

Triyanto. Model Pembelajaran Terpadu. Jakarta: PT Bumi Aksa 